\title{
Genetic Variability, Correlation and Path Coefficient Analysis in F2 Segregating Population in Tomato (Solanum lycopersicum L.)
}

\author{
P. Gopinath* and P. Irene Vethamoni \\ Department of Vegetable Crops \\ Tamil Nadu Agricultural University, Coimbatore-641 003
}

\begin{abstract}
Genetic variability, heritability and genetic advance for fifteen yield contributing traits were studied in $F_{2}$ population obtained from the cross of Arka Vikas $\times$ EC 519809. The study indicated that existence of considerable amount of genetic variability for all the characters studied. The characters viz., fruit yield per plant, number of fruits per plant, number of primary branches, total phenol and pericarp thickness exhibited higher values of genotypic and phenotypic coefficient of variation. Whereas, fruit yield per plant, individual fruit weight, pericarp thickness and number of primary branches per plant exhibited high estimates of heritability and genetic advance for yield per plant and average fruit weight. These characters can be effectively improved through selection. Correlation indicated that yield was significantly and positively associated with plant height, number of flowers per cluster, percent fruit set, fruit length, fruit diameter, individual fruit weight and number of fruits per plant. Number of fruits per cluster and number of fruits per plant showed the highest positive direct effect on fruit yield per plant. Direct selection may be executed considering these traits as the main selection criteria to reduce indirect effect of other characters during development of high yielding tomato variety.
\end{abstract}

Key words: Variability, $F_{2}$ Segregating Population, Correlation, Path analysis, Tomato

Tomato (Solanum lycopersicon Mill.) is one of the most important Solanaceous vegetable crops originated from Peru region which is grown widely all over the world. It is one of the most important "Protective foods" because of its special nutritive value. In many countries it is considered as "poor man's orange" because of its attractive appearance and nutritive value. The red pigment in tomato (lycopene) is now being considered as the "world's most powerful natural antioxidant".

$F_{2}$ generation obtained from selfing of $F_{1}$ hybrid provides all possible variations. So, selection with particular objectives in $F_{2}$ generation is very much effective and selfing of those selected genotypes generation after generation helps to develop inbred lines (similar to the parental lines of the exotic hybrids). The estimates of genotypic and phenotypic coefficients of variation, provide an idea of interplay of the genotype and environment that influences breeding results (Taiana et al., 2015). High heritability and high genetic advance for a given trait indicates that it is governed by additive gene action and therefore, provides the most effective condition for selection. Correlation studies between fruit yield and its components and their relative contribution to yield are of value in planning a breeding programme. Path analysis facilitates the partitioning of the correlation coefficient into direct and indirect effects on yield and any other attributes (Islam et al., 2010, Kumar

*Corresponding author email: gopihorti@gmail.com et al., 2013). Path coefficient analysis is also very useful in formulating breeding strategy to develop elite genotypes through selection in advanced generations. Hence, the present study was carried out to assess the performance of various economic traits and to measure the extent of variability, heritability, expected genetic advance, correlation and path coefficient analysis components in tomato.

\section{Material and Methods}

The experiment was carried out at the College Orchard, Department of Vegetable Crops, Horticultural College and Research Institute, Tamil Nadu Agricultural University, Coimbatore. Totally $250 \mathrm{~F}_{2}$ tomato plants derived from the cross Arka Vikas $\times$ EC 519809 were evaluated for high yield and yield contributing characters during the year 2016-2017. The $F_{2}$ progenies obtained by selfing from the $F_{1}$ cross were raised.

Each plant in the cross was labelled for recording fifteen quantitative and qualitative characters, which includes plant height $(\mathrm{cm})$, number of primary branches, days to first flowering, number of flower per cluster, number of fruits per cluster, fruit setting percentage, fruit length $(\mathrm{cm})$, fruit diameter $(\mathrm{cm})$, number of locules per fruit, pericarp thickness $(\mathrm{mm})$, individual fruit weight $(\mathrm{g})$, number of fruits per plant, yield per plant $(\mathrm{kg})$, TSS ( ${ }^{\circ}$ Brix) and total phenol $(\mu \mathrm{g} / \mathrm{g})$. Genotypic coefficient of variation (GCV), phenotypic coefficient of variation (PCV), heritability in broad sense $\left(h^{2}\right)$ and genetic advance (GA) and 
genetic advance as percentage over mean were analyzed following the formula illustrated by Singh and Chaudhary (1997). The correlation coefficient was estimated according to formula given by Johnson et al. (1955). The direct and indirect paths were obtained according to the method of Dewey and Lu (1959).

Table 1. Mean, Range and genetic parameters in F2 population of the tomato hybrid Arka Vikas $\times$ EC 519809

\begin{tabular}{|c|c|c|c|c|c|c|c|}
\hline Characters & Mean & Range & PCV & GCV & h2 & GA & GA as $\%$ mean \\
\hline No. of primary branches/plant & 3.90 & $2.00-6.00$ & 34.03 & 27.629 & 65.93 & 1.90 & 48.68 \\
\hline Days to first flowering & 31.00 & $26.00-36.00$ & 8.80 & 5.770 & 42.95 & 2.54 & 8.21 \\
\hline No. of Flowers/cluster & 6.10 & $4.60-7.40$ & 9.01 & 5.224 & 33.65 & 0.40 & 6.58 \\
\hline No. of fruits/cluster & 4.20 & $2.80-5.60$ & 12.91 & 5.001 & 15.01 & 0.18 & 4.20 \\
\hline Fruit length $(\mathrm{cm})$ & 6.36 & $4.64-7.58$ & 9.51 & 6.623 & 48.54 & 0.64 & 10.01 \\
\hline Fruit diameter $(\mathrm{cm})$ & 4.49 & $3.24-5.64$ & 9.77 & 5.745 & 34.54 & 0.33 & 7.33 \\
\hline No. of locules /fruit & 3.65 & $3.00-4.40$ & 9.84 & 5.106 & 26.92 & 0.21 & 5.75 \\
\hline Pericarp thickness (mm) & 3.46 & $0.75-5.03$ & 24.99 & 21.872 & 76.60 & 1.44 & 41.54 \\
\hline TSS (0 Brix) & 8.93 & $8.00-10.40$ & 6.72 & 5.626 & 70.15 & 0.91 & 10.23 \\
\hline Total Phenol $(\mu \mathrm{g} / \mathrm{g})$ & 0.32 & $0.06-0.54$ & 36.64 & 22.520 & 37.78 & 0.10 & 30.04 \\
\hline
\end{tabular}

advance as percent mean (GA \%) in $\mathrm{F}_{2}$ population of cross Arka Vikas $\times$ EC519809 are shown in the table 1.

Results showed that the genotypic coefficient of variation was observed highest for fruit yield per plant $(33.08 \%)$, followed by number of primary branches per plant $(27.63 \%)$, number of fruits per plant $(24.19 \%)$, total phenol $(22.52 \%)$ and pericarp

\section{Results and Discussion}

Variability plays an important role in crop breeding material ensures the better chance of producing desirable crop plant. The results of range, mean, genotypic coefficient of variation (GCV), phenotypic coefficient of variation (PCV), heritability $\left(\mathrm{h}^{2}\right)$, genetic

Table 2. Simple correlation coefficient between fruit yield and yield components traits in F2 generation of the cross Arka Vikas × EC 519809

\begin{tabular}{|c|c|c|c|c|c|c|c|c|c|c|c|c|c|c|c|}
\hline $\mathrm{PH}$ & NPB & DFF & NFC & FPC & PFS & $\mathrm{FL}$ & FD & NLF & PT & IFW & FPP & TSS & TP & FYP & \\
\hline $\mathrm{PH}$ & 1.000 & $-0.486^{* *}$ & -0.003 & 0.090 & 0.090 & 0.025 & 0.119 & 0.054 & -0.063 & 0.021 & $0.258^{\star *}$ & 0.048 & 0.012 & 0.108 & $0.142^{*}$ \\
\hline NPB & & 1.000 & 0.021 & $0.148^{*}$ & 0.072 & -0.038 & $0.147^{*}$ & 0.057 & 0.045 & -0.107 & 0.076 & 0.112 & 0.054 & 0.050 & 0.112 \\
\hline NFC & & & & 1.000 & $0.600^{\star *}$ & $-0.130^{\star}$ & $0.220^{* *}$ & 0.110 & -0.056 & -0.086 & $0.269^{\star *}$ & 0.099 & -0.077 & $0.151^{*}$ & $0.221^{\star \star}$ \\
\hline FPC & & & & & 1.000 & $0.712^{\star *}$ & 0.044 & 0.047 & -0.082 & -0.103 & $0.139^{*}$ & -0.021 & -0.028 & 0.072 & 0.027 \\
\hline $\mathrm{FL}$ & & & & & & & 1.000 & $0.150^{*}$ & 0.016 & 0.023 & $0.350^{* *}$ & $0.142^{*}$ & -0.083 & $0.265^{\star *}$ & $0.258^{\star \star}$ \\
\hline FD & & & & & & & & 1.000 & 0.001 & -0.013 & $0.156^{*}$ & $0.191^{* *}$ & -0.046 & 0.062 & $0.200^{\text {** }}$ \\
\hline NLF & & & & & & & & & 1.000 & 0.069 & -0.019 & -0.053 & -0.035 & -0.047 & -0.044 \\
\hline PT & & & & & & & & & & 1.000 & -0.011 & 0.055 & -0.029 & -0.021 & 0.024 \\
\hline AFW & & & & & & & & & & & 1.000 & $0.323^{\star *}$ & -0.043 & $0.314^{* *}$ & $0.426^{\star *}$ \\
\hline TP & & & & & & & & & & & & & & 1.000 & $0.272^{\star \star}$ \\
\hline FYP & & & & & & & & & & & & & & & 1.000 \\
\hline \multicolumn{6}{|c|}{$\begin{array}{l}{ }^{*} \text { Significant at } 5 \% \text { level and }{ }^{* *} \text { Significan } \\
\text { PH }=\text { Plant height }(\mathrm{cm}) \\
\text { NPB }=\text { No. of primary branches } \\
\text { DFF }=\text { Days to first flowering } \\
\text { NFC }=\text { No. of flower per cluster }\end{array}$} & \multicolumn{5}{|c|}{$\begin{array}{l}\mathrm{PFS}=\text { Percent fruit set }(\%) \\
\mathrm{FL}=\text { Fruit length }(\mathrm{cm}) \\
\mathrm{FD}=\text { Fruit diameter }(\mathrm{cm}) \\
\mathrm{NLF}=\text { No. of locules per fruit }\end{array}$} & & \multicolumn{4}{|c|}{$\begin{array}{l}\text { IFW }=\text { Individual fruit weight }(\mathrm{g}) \\
\mathrm{FPP}=\text { No. of fruits per plant } \\
\text { FYP }=\text { Yield per plant } \\
\text { TSS }=\text { Total soluble solids }(0 \text { brix })\end{array}$} \\
\hline \multicolumn{6}{|c|}{$\mathrm{FPC}=$ No. of fruits per cluster } & \multicolumn{6}{|c|}{$\mathrm{PT}=$ Pericarp thickness $(\mathrm{mm})$} & \multicolumn{4}{|c|}{$\mathrm{TP}=$ Total phenol $(\mu \mathrm{g} / \mathrm{g})$} \\
\hline
\end{tabular}


The highest phenotypic coefficient of variation was recorded for total phenol $(36.64 \%)$, followed by number of fruits per plant $(36.16 \%)$, fruit yield per plant $(34.52 \%)$, number of primary branches per plant $(34.03 \%)$ and pericarp thickness $(24.99 \%)$, while moderate in individual fruit weight $(19.49 \%)$, followed by plant height $(13.27 \%)$, number of fruits per cluster $(12.91 \%)$ and fruit set percent $(10.48 \%)$, and lowest recorded by number of locules per fruit $(9.84 \%)$ followed by fruit diameter $(9.77 \%)$, fruit length $(9.51 \%)$, number of flowers per cluster $(9.01 \%)$, days to first flowering (8.80\%) and TSS (6.72\%).
Higher GCV and PCV were recorded for characters like fruit yield per plant, number of fruits per plant, number of primary branches, total phenol and pericarp thickness indicating higher magnitude of variability for these characters. In general, higher names of phenotypic coefficient of variation than genotypic coefficient of variation were recorded for all the traits. These findings were similar to Firas AlAysh et al. (2012), Reddy et al. (2013), Sharanappa and Mogali (2014), Ullah et al. (2015) and Rai et al. (2016) in tomato.

Table 3. Path co efficient on fruit yield per plant in $F_{2}$ generation of the cross Arka Vikas $\times$ EC 519809

\begin{tabular}{|c|c|c|c|c|c|c|c|c|c|c|c|c|c|c|c|}
\hline $\mathrm{PH}$ & NPB & DFF & NFC & FPC & PFS & $\mathrm{FL}$ & FD & NLF & PT & IFW & FPP & TSS & TP & FYP & \\
\hline $\mathrm{PH}$ & 1.000 & $-0.486^{* *}$ & -0.003 & 0.090 & 0.090 & 0.025 & 0.119 & 0.054 & -0.063 & 0.021 & $0.258^{\star *}$ & 0.048 & 0.012 & 0.108 & $0.142^{*}$ \\
\hline NPB & & 1.000 & 0.021 & $0.148^{*}$ & 0.072 & -0.038 & $0.147^{\star}$ & 0.057 & 0.045 & -0.107 & 0.076 & 0.112 & 0.054 & 0.050 & 0.112 \\
\hline NFC & & & & 1.000 & $0.600^{\star *}$ & $-0.130^{*}$ & $0.220^{\star *}$ & 0.110 & -0.056 & -0.086 & $0.269^{\star \star}$ & 0.099 & -0.077 & $0.151^{*}$ & $0.221^{\text {** }}$ \\
\hline FPC & & & & & 1.000 & $0.712^{\star \star}$ & 0.044 & 0.047 & -0.082 & -0.103 & $0.139^{\star}$ & -0.021 & -0.028 & 0.072 & 0.027 \\
\hline $\mathrm{FL}$ & & & & & & & 1.000 & $0.150^{*}$ & 0.016 & 0.023 & $0.350^{\star *}$ & $0.142^{*}$ & -0.083 & $0.265^{\star *}$ & $0.258^{\star \star}$ \\
\hline FD & & & & & & & & 1.000 & 0.001 & -0.013 & $0.156^{\star}$ & $0.191^{\text {** }}$ & -0.046 & 0.062 & $0.200^{* *}$ \\
\hline NLF & & & & & & & & & 1.000 & 0.069 & -0.019 & -0.053 & -0.035 & -0.047 & -0.044 \\
\hline PT & & & & & & & & & & 1.000 & -0.011 & 0.055 & -0.029 & -0.021 & 0.024 \\
\hline AFW & & & & & & & & & & & 1.000 & $0.323^{\star *}$ & -0.043 & $0.314^{\star \star}$ & $0.426^{\star \star}$ \\
\hline TP & & & & & & & & & & & & & & 1.000 & $0.272^{\star \star}$ \\
\hline FYP & & & & & & & & & & & & & & & 1.000 \\
\hline
\end{tabular}

*Significant at $5 \%$ level and **Significant at $1 \%$ level

Residual effect $=0.245$

$\mathrm{PH}=$ Plant height $(\mathrm{cm})$
$\mathrm{NPB}=$ No. of primary branche

$\mathrm{NPB}=$ No.of primary branches
$\mathrm{DFF}=$ Days to first flowering

$\mathrm{DFF}=$ Days to first flowering
$\mathrm{NFC}=$ No. of flower per cluster

PFS = Percent fruit set $(\%)$

$\mathrm{FL}=$ Fruit length $(\mathrm{cm})$

$\mathrm{FD}=$ Fruit diameter $(\mathrm{cm})$

$\mathrm{NLF}=$ No. of locules per fruit
$\mathrm{PT}=$ Pericarp thickness $(\mathrm{mm})$
IFW = Individual fruit weight $(\mathrm{g})$

$\mathrm{FPP}=$ No. of fruits per plan

FYP $=$ Yield per plant

TSS $=$ Total soluble solids $(0$ brix $)$
TP $=$ Total phenol $(\mu \mathrm{g} / \mathrm{g})$

$\mathrm{FPC}=$ No. of fruits per cluster

Highest value of heritability was noticed in fruit yield per plant $(91.84 \%)$, followed by individual fruit weight $(77.14 \%)$, pericarp thickness $(76.60 \%)$, TSS $(70.15 \%)$ and $(65.93 \%)$ in number of primary branches per plant. The results confirmed the involvement of additive gene action in these traits with less environment influence. Lowest value of heritability was recorded by number of fruits per cluster $(15.01 \%),(26.53 \%)$ in fruit set percent and number of locules per fruit (26.92\%).

Genetic advance as percent of mean was highest $(68.79 \%)$, followed by number of primary branches per plant $(48.68 \%)$, pericarp thickness $(41.54 \%)$, number of fruits per plant (35.14\%), individual fruit weight $(32.62 \%)$ and total phenol $(30.04 \%)$. Lower value for $\mathrm{GA} \%$ was observed in number of fruits per cluster $(4.20 \%)$, followed by number of locules per fruit $(5.75 \%)$, fruit set percent $(6.04 \%)$, number of flowers per cluster $(6.58 \%)$, fruit diameter $(7.33 \%)$, days to first flowering $(8.21 \%)$, fruit length $(10.01 \%)$, TSS $(10.23 \%)$ and plant height $(12.97 \%)$ respectively.

High estimates of heritability with high genetic advance as percent over mean were recorded for fruit yield per plant, individual fruit weight, pericarp thickness and number of primary branches per plant. These findings are similar to Mehta and Asati (2008), Reddy et al. (2013), Ullah et al. (2015) and Rai et al. (2016). It might be assigned to be under the control of additive genes and phenotypic selection for their improvement could be achieved by simple breeding methods.

\section{Correlation studies}

The correlation between fruit yield per plant with different yield attributes are presented in (table 2). The correlation coefficient among different characters indicated that yield per plant was significant and positively associated with plant height $(0.142)$, number of flowers per cluster (0.221), per cent fruit set (0.163), fruit length (0.258), fruit diameter $(0.200)$, individual fruit weight (0.426), number of fruits per plant $(0.803)$ and total phenol $(0.272)$. These results are in agreement with findings of Meena et al. (2015), Phom et al. (2015), Ullah et al. (2015), Meena and Bahadur (2015), Rahman et al. (2015) and Hazim et al. (2016) in tomato.

The plant height exhibited positive and significant relationship with individual fruit weight (0.258). Number of primary branches per plant showed 
positive and significant association with number of flowers per cluster (0.148) and fruit length (0.147). Similar results were also obtained by Mayavel et al. (2005). Number of flowers per cluster had positive and significant correlation with number of fruits per cluster (0.600), fruit length (0.220), fruit weight (0.269). These results are in accordance with the reports of Ullah et al. (2015) and Rahman et al. (2015). The number of fruits per cluster was positively and significantly correlated to percent fruit set (0.712) and individual fruit weight $(0.139)$. These results are in conformity with the findings of Sherpa et al. (2014). The fruit length had positive and significant association with fruit diameter (0.150), average fruit diameter $(0.350)$ and number of fruits per plant (0.142). The result is in agreement with the findings of Mahapatra et al. (2013) and Rahman et al. (2015). Fruit diameter recorded positive and significant correlation with individual fruit weight (0.156) and number of fruits per plant (0.191). Other studies reported by Mahapatra et al. (2013), Kumar et al. (2013) and Chernet et al. (2013) are also same with this findings. The individual fruit weight was positively and significantly correlated with number of fruits per plant (0.323) and total phenol (0.314). These results are in conformity with the findings of Mahapatra et al. (2013).

\section{Path coefficient analysis}

Although correlation studies are helpful in determining components of yield, with the inclusion of more variables in correlation studies, the indirect association becomes more complex. Two characters may show a correlation because they correlate with a common third one. Under such circumstances, path analysis helps in partitioning of correlation coefficients into direct and indirect effects, permitting a critical examination of the relative importance of each trait.

The path coefficient analysis in (table 3 ) revealed that high positive direct effect on fruit yield per plant was exerted by number of fruits per cluster (0.339) and number of fruits per plant $(0.727)$. The highest negative direct effect on fruit yield per plant was noted by percent fruit set $(-0.328)$. The individual fruit weight recorded lowest positive direct effect of 0.105 on fruit yield. The lowest negative direct effect on fruit yield per plant was exerted by number of flowers per cluster $(-0.155)$. This character showing high direct effect on yield per plant indicated that direct selection for these traits might be effective and there is a possibility of improving yield per plant through selection based on these characters. Similar results of direct positive effects for those traits was reported by Meena and Bahadur (2015), Ullah et al. (2015) and Nagariya et al. (2015).

On the other hand, positive indirect effects of number of flowers per cluster, percent fruit set, fruit length, fruit diameter, individual fruit weight, total phenol through number of fruits per plant to yield per plant was also observed. Similar results for indirect effects were recorded by Islam et al. (2010) and Meena and Bahadur (2015).

\section{Conclusion}

In respect of fruit yield, which is the most important character in an improvement programme, high heritability coupled with high genetic advance was recorded. It indicates the chances for wide range for selection in $F_{2}$ population of the cross Arka Vikas $\times$ EC519809 and the yield per plant was positively and significantly correlated with plant height, number of flowers per cluster, percent fruit set, fruit length, fruit diameter, individual fruit weight and number of fruits per plant. In path coefficient analysis the highest positive direct effect was noted in number of fruits per cluster and number of fruits per plant. Hence, these traits can further be exploited by direct selection for genetic improvement in tomato to bring about the improvement in yield.

\section{References}

Chernet, S., D. Belew and F. Abay. 2013. Genetic variability and association of characters in tomato (Solanum lycopersicum L.). Int. J. Agric. Res., 1: 1-10.

Dewey, D.R. and K.N. Lu. 1959. A correlation and path coefficient analysis of components of crested wheat grass seed production. Agron. J., 51: 515-518.

Firas Al-Aysh, Mohmood Al-Serhan, Adnan AlShareef, Mohammad Al-Nasser and Hussein Kutma. 2012. Study of genetic parameters and character interrelationship of yield and some yield components in tomato (Solanum lycopersicum L.). Inter. J. Genet., 2(2):29-33.

Hazim, Z., D. Al-Qurashi, N. Rahmatzia, A. Ahmady and A.A. Mousa. 2016. Variability and character association in inter-specific $\mathrm{F}_{2}$ tomato population (Lycopersicon esculentum L.). Int. J. Adv. Res., 4(11): 2353-2358.

Islam, B.M.R., N.A. Ivy, M.G. Rasul and M. Zakaria. 2010. Character association and path analysis of exotic tomato (Solanum lycopersicum L.) genotypes. Bangaladesh J. Plant Breed. Genet., 23 (1): 13 -18.

Kumar, D., R. Kumar, S. Kumar, M.L. Bhardwaj, M.C. Thakur, R. Kumar, K.S. Thakur, B.S. Dogra, A. Vikram, A. Thakur and P. Kumar. 2013. Genetic variability, correlation and path coefficient analysis in tomato. Int. J. Veg. Sci., 19: 313-323.

Mahapatra, S.A., A.K. Singh, M.V. Vani, R. Mishra, H. Kumar and B.V. Rajkumar. 2013. Inter-relationship for various components and path coefficient analysis in tomato (Lycopersicum esculentum Mill.). Int. J. Curr. Microbiol. App. Sci., 2(9): 147-152.

Mayavel, A., G. Balakrishnamurthy and S. Natarajan. 2005. Variability and heritability studies in tomato hybrids. South Indian Hort., 53 (1-6): 262-266.

Meena, O.P. and V. Bahadur. 2015. Genetic associations analysis for fruit yield and its contributing traits on indeterminate tomato (Solanum lycopersicum L.) germplasm under open field condition. J. Agric. Sciences., 7: 3-10.

Meena, O.P., V. Bahadur, A.B. Jagtap, P. Saini and Y.K. Meena. 2015. Genetic variability studies of fruit yield and its traits among inderterminate tomato genotypes under open filed condition. African. J. Agri. Res., Vol. 10 (32): 3170-3177.

Mehta, N. and B. Asati. 2008. Genetic relationship of growth and development traits with fruit yield in tomato (Lycopersicum esculentum Mill.). Karnataka J. Agric. Sci., 21(1): 92-96. 
Nagariya, N.K., R. Bhardwaj, N. Sharma, S. Mukherjee and Umesh. 2015. Correlation and path analysis in tomato, (Solanum lycopersicum L.). Inter. J. farm sciences., 5(4): 111-117.

Phom, M., H.P. Chaturvedi and S.P. Kanaujia. 2015. Genetic variability, character association and path coefficient analysis in tomato (Lycopersicon esculentum Mill.) genotypes. Plant Archives., Vol.15(1): 519-522.

Rahman, Md.S, S. Parveen, Md.H. Rashid, R. Akter, A.Y. Hossin and Md.G. Robbani. 2015. Correlation and path coefficient analysis of tomato germplasms. Int. J. Appl Sci Biotechnol., Vol 3 (2): 223 - 226

Rai, A. K., A. Vikram and A. Pandav.2016. Genetic variability studies in tomato (Solanum lycopersicum L.) for yield and quality traits. Inter. J. Agri, Environment and Biotech., 9(5): 739-744.

Reddy, B.R., D.S. Reddy, K. Reddaiah and N. Sunil. 2013 Studies on genetic variability, heritability and genetic advance for yield and quality traits in tomato (Solanum lycopersicum L.). Int. J. Curr. Microbiol. App. Sci., 2(9): 238-244.
Sharanappa, K. P and Mogali, S. C. 2014. Studies on genetic variability, heritability and genetic advance for yield and yield components in $\mathrm{F}_{2}$ segregating population of tomato (Solanum lycopersicon L.) Karnataka J. Agric. Sci., 27(4): 524-525.

Sherpa, P., N. Pandiarana, V.D. Shende, T. Seth, S. Mukherjee and A. Chattopadhyay. 2014. Estimation of genetic parameters and identification of selection indices in exotic tomato genotypes. Electron. J. Plant Breed., 5(3): 552-562.

Singh, P.K. and R.D. Choudhary. 1977. Biometrical methods. In: Quantitative Genetic Analysis, Kalyani publishers, New Delhi. 178 -185.

Taiana, T., M.H. Rashid, S. Parveen, Md. S. Hossain and Md. A. Haque. 2015. Selection strategies to choose better parents in tomato using genetic parameters. Plant Knowledge Journal., 4(1): 33-39.

Ullah, M. Z., L. Hassan, S. B. Shahid and A. K. Patwary.2015. Variability and inter relationship studies in tomato (Solanum lycopersicum L.). J. Bangladesh. Agri. Univ., 13 (1): 65-69. 